\title{
不均質溥膜による反射防止 ${ }^{*}$
}

\author{
小 瀨 輝 次 \\ 久保田廣
}

(東京大学第二工学部)

\section{1 緒}

論

一般に反射防止膜に関する議論は膜の屈折率が厚さによつて变ら奴均一なものとして行つているので あるが，此の場合單一膜では反射光か澪となる为の條件として，膜の厚さを $d$, 屈折率を $n$, 用らる波長 を入，确子の屈折率をn，とすれば

$$
n d=\frac{\lambda}{4},
$$$$
n=\sqrt{n_{!}}
$$

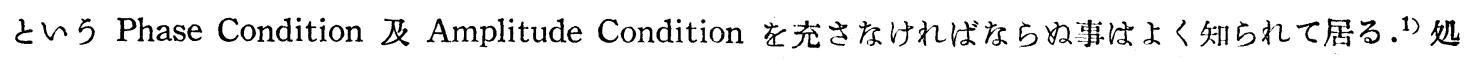
が Phase Condition は技術的红可成正確に充す事多可能なのであるが, Amplitude Condition は現 在知られて居る物質では充分な固さを保をしめつつ之の條件を充す事以困難なので，実用に耐へ得る單 一膜では嚴密に反射防止をするととが出來ないのである，そとで完全な反射防止をする為に最近では二 重虚膜，三重層膜による反射防止が試みられて居るのであるが，之をつける操作はかなり面倒であるの で，今な和広く單一膜が用いられて居る。

然しながら実際にガラス面上の薄膜は屈折率が均一之考元たのでは說明出來好昜合もあり .27以上の

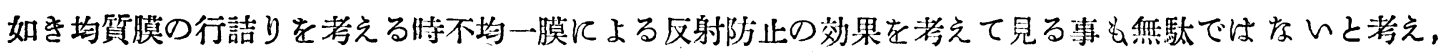
以下の議論及び実驗を試みそ次第である。

\section{2 理 論 の 概 觀}

此の問題を噘密て解くには Maxwell の電磁昜の基礎方程式を, 所與の境界佟件で解くといら事にな るが之は結局

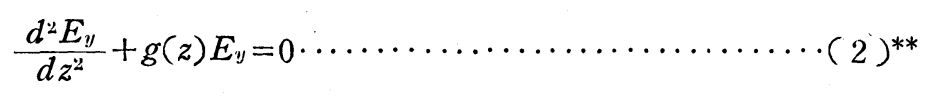

なる微分方程式を與えられを境界條件で船けばよいのであるが，之については多数の人ふにより種々の

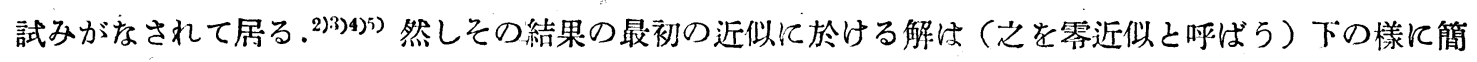
單に考えられる。

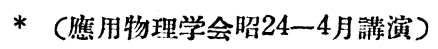

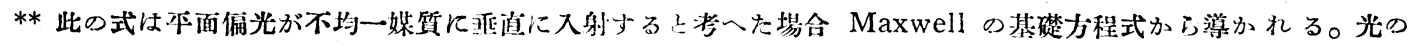

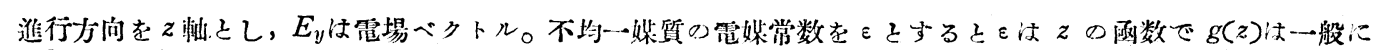
$\left(\frac{2 \pi}{\lambda} n(z)\right)^{2}$ で與へられる。 $n$ は不均一媒質彺折率で $n^{2}=\varepsilon(z)$ でおる。 


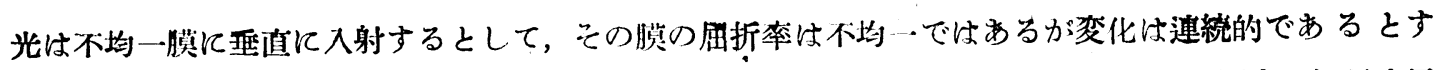
ると反射の起るのは雨境界のみであるから ${ }^{3)}$ その各々の反射係数を $B, C$ とると (第 1 図参照) 累次反 射を考えて反射率は

$$
R=\frac{B^{2}+C^{2}+2 B C \cos S}{1+B^{2} C^{2}+2 B C \cos S} \cdots \cdots \cdots(3)
$$

で與えられる.1 之が零である為には分子が零であればよいから*

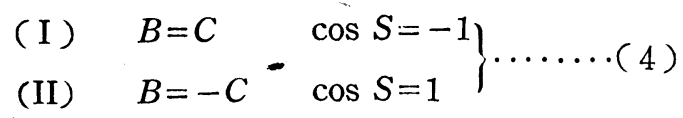

の二つの場合があるととは容易にわかる。

第一図の样に均一媒質の届折率を $n, n^{\prime}$, 不均一媒質の両境界

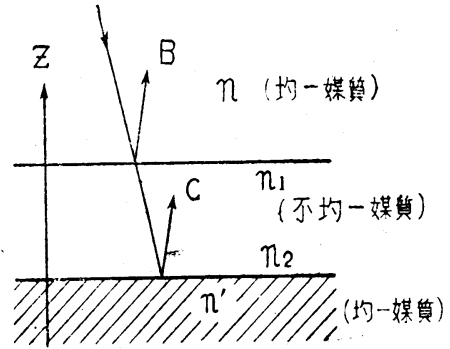

策1図 の屈折を $n_{1}, n_{2}$ とすると反射係数 $B, C$ は,

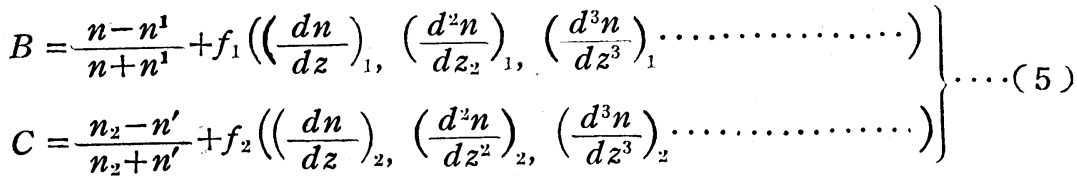

$$
\begin{aligned}
& S=\frac{4 \pi}{\lambda} \int_{0}^{a} n(z) d z
\end{aligned}
$$

で與えられる。

然し $\left(\frac{d n}{d z}\right),\left(\frac{d^{2} n}{d z^{2}}\right)$ の第一項に対する大きさは 1 に対して $\lambda / 4 \pi \frac{n^{\prime}}{n},(\lambda / 4 \pi)^{2} \frac{n^{\prime \prime}}{n} \quad$ 但 $n^{\prime}=\frac{d n}{d z}$, $n^{\prime \prime}=\frac{d^{2} n}{d z^{2}}$ の大きさである事が証明出來る4) から今之を 1 亿対して省略し得るとすると（4）式は

$$
\begin{gathered}
\text { (I) } n n^{\prime}=n_{1} n_{2} \int_{0}^{l} n(z) d z=\frac{\lambda}{2}\left(k+\frac{1}{2}\right) \\
\text { (II) } \frac{n^{\prime}}{n}=\frac{n_{2}}{n_{1}} \int_{0}^{l} n(z) d z=\frac{\lambda}{2} k \\
k=1,2,3 \cdots \cdots \text { である。 }
\end{gathered}
$$

之が不均一膜の (0次近似の時の) Amplitude 及 Phase Condition となる. 今 $n=1$ 即ち第一媒質 を空氣と考えると $n_{1}>1$ であるから（I）の場合は $n_{2}<n^{\prime}$ となり膜の屈折率が第二の媒質（例えばカ ラス）の涵折率を越える事はなく大して興味はないが (II) の場合は $n_{2}>n^{\prime}$ となり第二の媒質よりも高 い届折率のものでも反射率を零ならしめる事が可能である. 從つて届折率の高い, 固い膜を用いても反 射防止が可能である。そとで之の㨾な場合をも少し吟情して見る事にする。

* B,C, は有限且 0 でないとすると分子 0 と云ふ事は位相角の差が $\mathrm{S}$ ○, C, なる二つのベクトル和が 0 と なる事でそれには（4）の二つの場合がある・ 


\section{3 反射率の計算}

\section{(A) 分光反射率}

或波長入に対する反射率は（5）を（3）に代入して零近似で考えれば

$$
\begin{aligned}
& R=1-\frac{4 n n^{\prime} n_{1} n_{2}}{\left(n n_{2}+n_{1} n^{\prime}\right)^{2}+\left(n^{2}-n_{1}{ }^{2}\right)\left(n^{\prime 2}-n_{2}{ }^{2}\right) \sin ^{2} \frac{S}{2}} \cdots \cdots(7) \\
& \text { 但 } \quad S=\frac{4 \pi}{\lambda} \int_{0}^{a} n(z) d z=\frac{4 \pi}{\lambda} \delta, \quad \delta=\int_{0}^{a} n(z) d z
\end{aligned}
$$

で,考える波長に対して反射率 0 なる為には今の場合, $\frac{n^{\prime}}{n}=\frac{n^{2}}{n_{1}}$ (Amplitude Condition), $\delta=\frac{\lambda}{2} k$ (Phase Condition)，但 $k=1 ， 2 ， 3 \cdots$ でなりればならない。実際に用らるのは白色光であるから他の 波長の光に対しては残単反射がある。そてで或波長に対してのみ反射が 0 となるだけでは不十分で，残 首反射が出來るだけ少ないものが望ましいわけである，即ち分光反射曲線が出來るだけ Flat なものが 望ましいわけである. $n^{\prime}=1.5$ (Glass), $n=1$ (Air) とし，膜の厚さは Phase Condition を充す樣即ち $\delta=\frac{\lambda}{2}$ につけた時, $n_{1}, n_{2}$ の変化による分光反射率の変化を考えて見る. Amplitude Condition $n_{2} / n_{1}=1.5$ と孛るから之を充す樣な組合 せの場合 $(7)$ 式より $R$ を求めて見ると第 2 図の榢になる. Amplitude Condition を充さない場合は反射率が０亿なる処が なく, $n_{2} / n_{1}=1.2$ 及 2.0 の時は第 3 図 の樣浡る。

此の図から分光反射曲線は flat でな く残畄反射がかなりある事がわかるが， n即ちガラスとの境界に於ける属折率が 低程曲線は flat になり又 $n_{2} / n_{1}$ の比 の大きい程 Flat になる事がわかる. 此 の樣汇分光反射曲線は Flat ではするが Amplitude Condition を充さ好ものと Flat でないが Amplitude Conditionを 充すものといずれが白色光に対して効果 があるか檢討する必要がある.

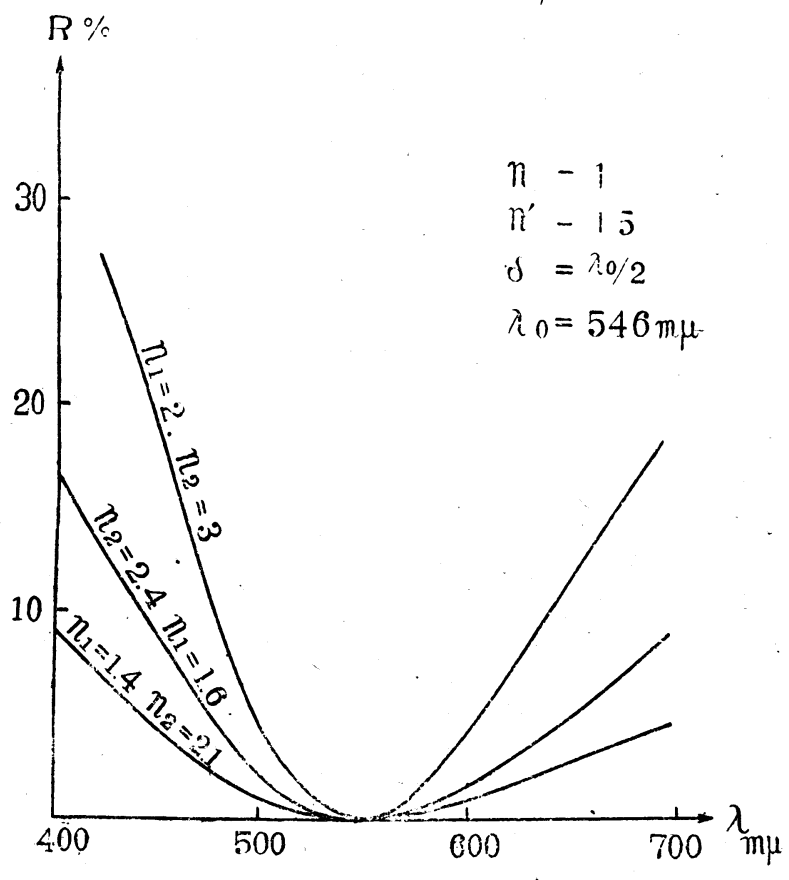

第 2 図

(B) 白色光几対する勃果

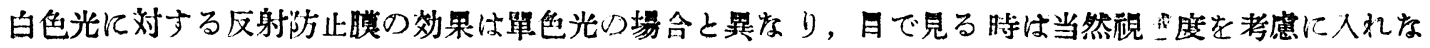

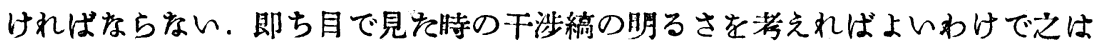




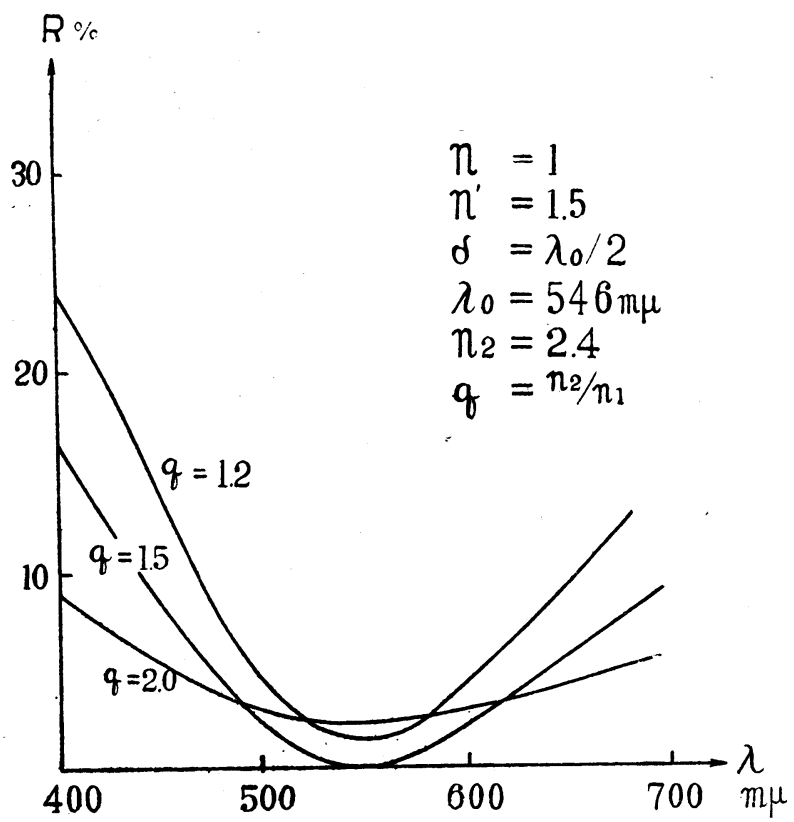

第3 図

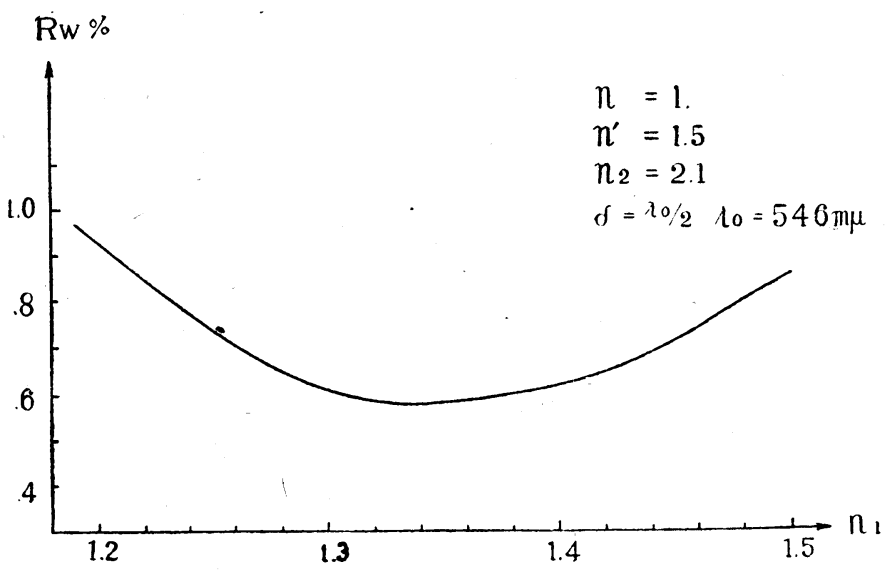

第 4 図

$$
R_{w}=\int_{\lambda 1}^{\lambda 2} E \bar{y} R d \lambda / \int_{\lambda 1}^{\lambda 2} E \bar{y} d \lambda \cdots
$$

で與えられる。但 $E$ は光源のエネルギー 分布, $\bar{y}$ は視感度, $R$ は膜の分光反射率 である。此の式の分子は I.C.I. 三色刺 戟值の Y Component を表して居る.

Phase Condition $\delta=\frac{\lambda}{2}$ は546m $\mu$ の 波長に対して充されて居るとして， $n_{2}=$ 2.10 時 $n_{1}$ に対して $R$ w 、 plot する と第 4 図*の樣になり $n_{1}=1.34$ の時最小 值 $0.59 \%$ を示す.

之の場合は $\frac{n_{2}}{n_{1}}=1.57$ になる。から 考えると，白色光に対する効果は， $\frac{n_{2}}{n_{1}}$ を大にして分光反射率曲線を flat にす るよりも，反射率曲線は flat でな いが, 悓感度の最大值附近 $(\lambda=$ $550 \mathrm{~m} \mu)$ で反射を零にした方が効 果がある事がわかる．此の事は單に 不均一膜に限らず均一膜に就ても闹 样にんえる事である。

（C）均一膜之不均一膜との比較 分光反射率曲線につへて不均一膜 を單一膜, 二重, 三重膜(7)73) と比較 すると第 5 図の樣になり, 不均一胋 $\left(n_{2}=2.1, n_{2} / n_{1}=1.5\right)$ と二重釐膜

$\left(n_{1}=1.47(\lambda / 4) \quad n_{2}=1.80(\lambda / 4)\right)$ とはよく似て居る事がわかる.

第 1 表 白色光隹する全反射率の比較

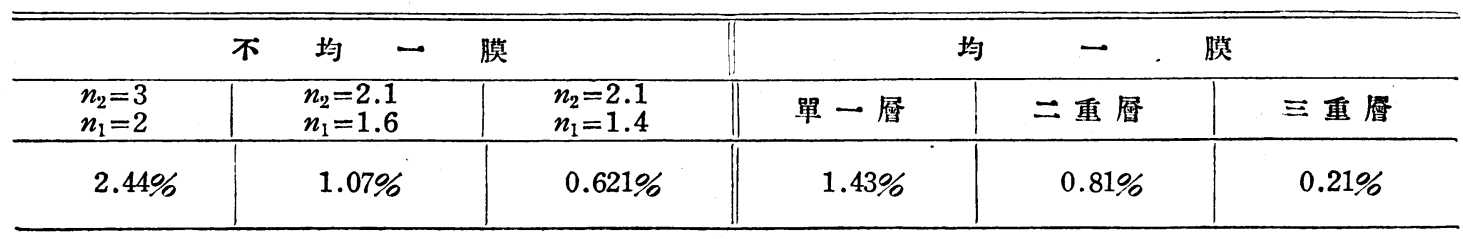




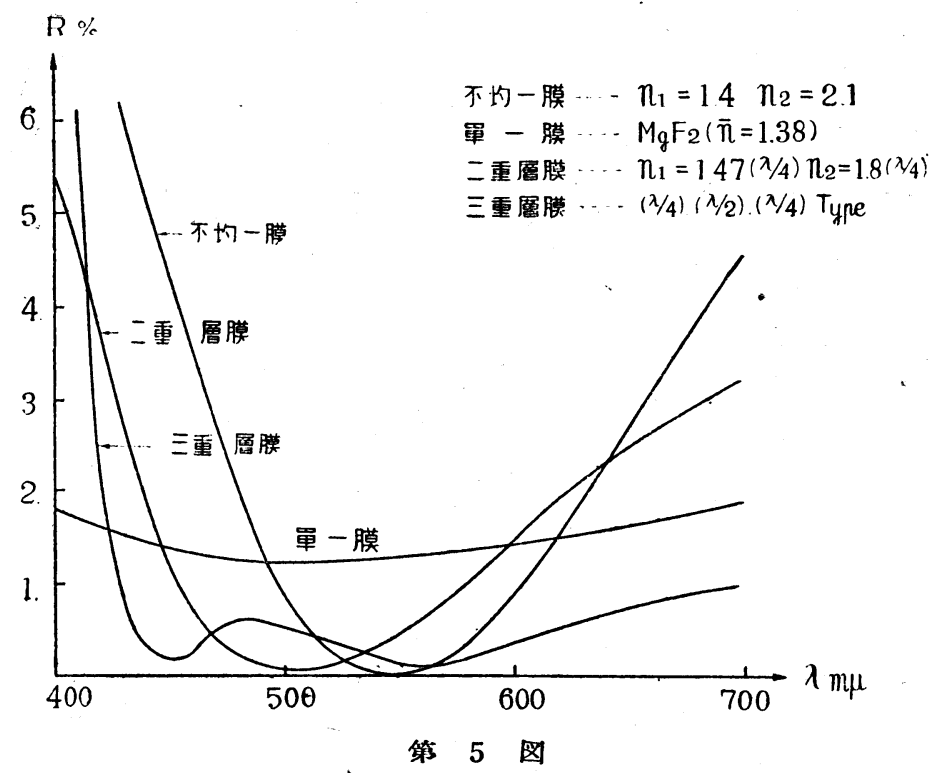

\section{4 許 容 詔 差}

実際に膜をつける際に希望通りの屈折來及厚さを得る事は不可能で当然誤差を伴ら．彷つて此の誤差 範囲が非常に狹い時は実用にならないといら事になるので許容誤差についてしらべて見る．Optical thickness $\frac{\lambda}{2}=273 \mathrm{~m} \mu$ の特 $n_{1}$ と $\lambda=546 \mathrm{~m} \mu$ に対する反射率との関係を $n_{2}$ を Parameter として 画レて見る之第 6 図の樣になり，之から反射率が $0.5 \%$ *以下である為には $n_{2}$ が與えられた場合 $n_{1}$ の許容 範囲は第二表の如く大体 $\Delta n_{1}=0.3 \sim 0.45$ 位となる.

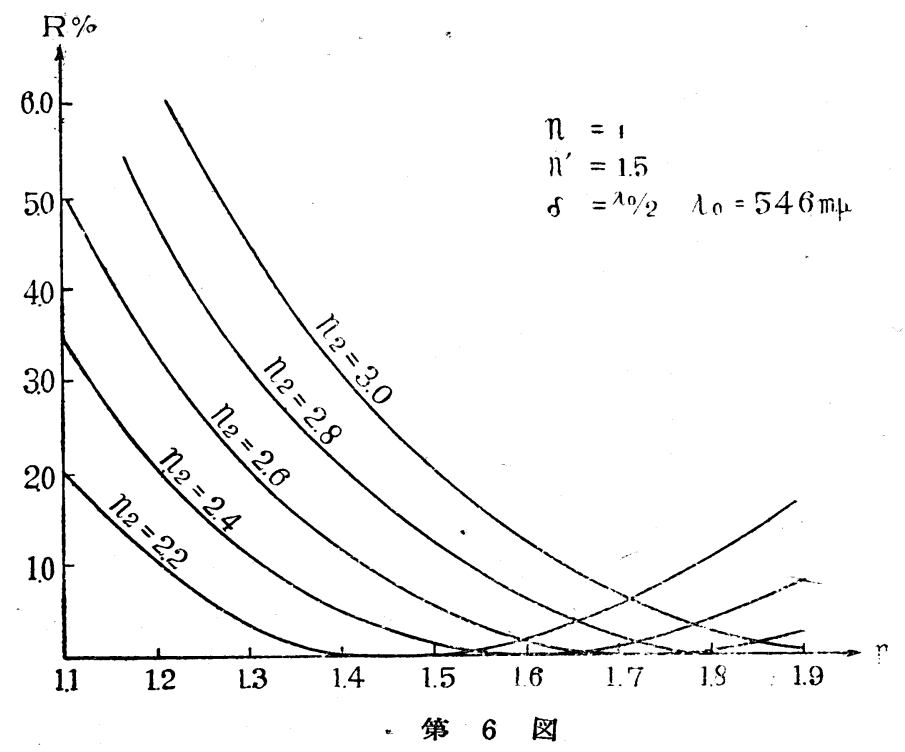

第 2 表

$n_{2}, \delta$ が興へられた時の $n_{1} の$ 伡容誤差

\begin{tabular}{l|l|l}
\hline \multicolumn{1}{c|}{$n_{2}$} & $n_{1}$ & $\Delta n_{1}$ \\
\hline 3 & $1.8 \sim 2.1$ & 0.3 \\
2.6 & $1.5 \sim 1.95$ & 0.45 \\
2.4 & $1.4 \sim 1.85$ & 0.45 \\
2.2 & $1.3 \sim 1.7$ & 0.4 \\
\hline
\end{tabular}

同樣にして， $n_{1}, n_{2}$ が與えられた 場合, 膜の Optical thickness の 許容範囲は $\Delta \delta=26 \sim 36 \mathrm{~m} \mu$ 位とな り，之の位のものであれば充分実用 になり得る。

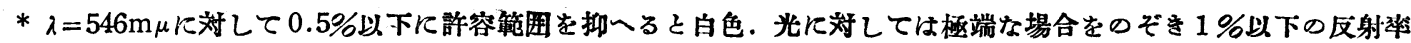
に抑一られる。 


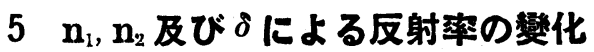

以上により不均一薄膜の反射防止の勃果は知曰得たのであるが，以下此の膜の特色を述べると，第一 に $n_{1}, n_{2}$ の組合せにより0から大きな反射率迄を自由に得られる事である.（5)(6)式からわかる样に 反射秉の極大極小值は

$$
\begin{aligned}
& \delta=\frac{\lambda}{2}(\text { 叉はとの整数倍) の処では } \\
& R=\left(\frac{n^{\prime}-n_{2} / n_{1}}{n^{\prime}+n_{2} / n_{1}}\right)^{2} \\
& \delta=\frac{\lambda}{4} \text { (刃は其の奇数倍) の処では } \\
& R=\left(\frac{n^{\prime}-n_{2} n_{1}}{n^{\prime}+n_{2} n_{1}}\right)^{2}
\end{aligned}
$$

で今 $n_{2} / n_{1}$ 义は $n_{1} n_{2}$ を $x$ と置くと $R$ の極大及極小值は

$$
R=\left(\frac{n^{\prime}-x}{n^{\prime}+x}\right)^{2}
$$

で表わされ” $n^{\prime}=1.5$ として $R$ と $x$ のグラフを画くと第 7 図の樣になる。

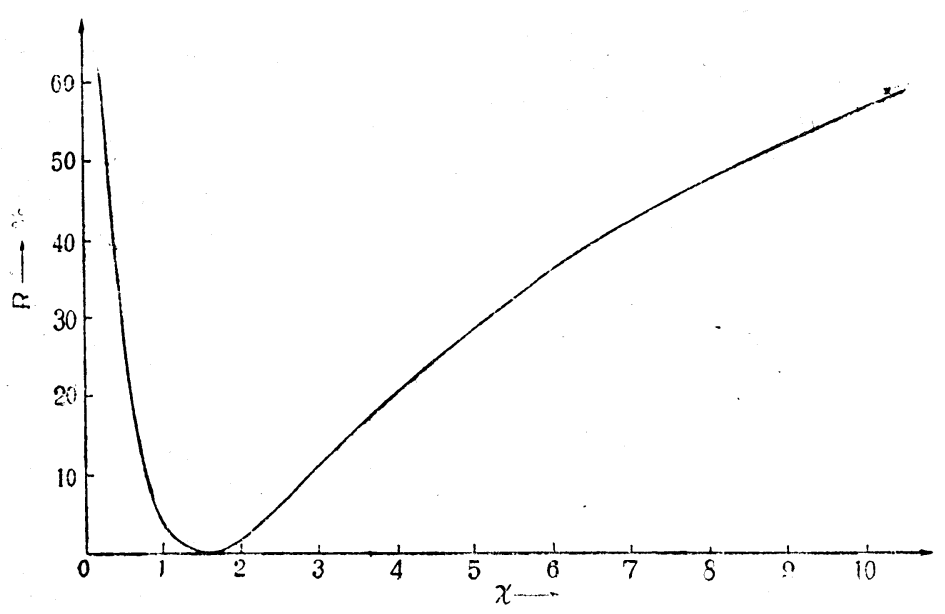

第 7 図

$n_{1}, n_{2}$ を適当に組合はせる事により， $\delta=\frac{\lambda}{4}$ ならばその積を $\delta=\frac{\lambda}{2}$ ならばその比を考えて所望の

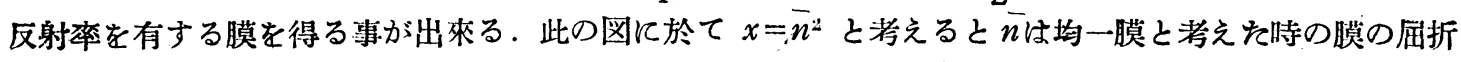
率にあたり, 此のととからも不均一の特色は $x<1$ 部分が用いられるといら点にあるとともわかる。

又 $\delta$ と $R$ の関係を見ると第 8 図の样になり $\delta$ を変へる事により 0 から大きな反射率の膜に至る迄 自由に作る事が出來る. 


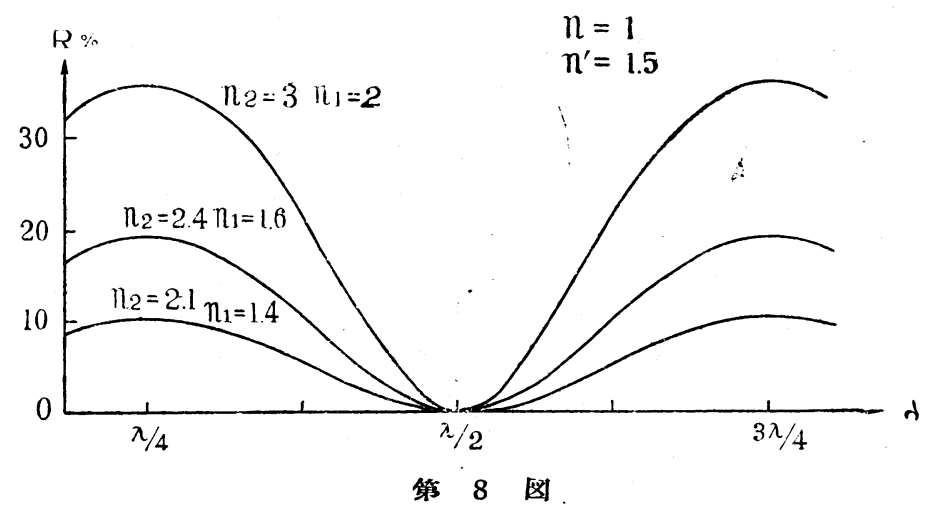

\section{6 賽驗}

不均質膜の上下両端に於ける届折率 $n_{1}$ 及 $n_{2}$ は実際には測定出來ぬ量である為物質の蒸着侍の真空度 と㐿折率の関係を予め数多くの実驗により確めて置かなりればならね. 然る後, Bell jar の中に二つの Source を置き，一方は低屈折率の物質（例えば $\mathrm{M}_{0} \mathrm{~F}_{2}$ ）他方には高㐿折率の物質（例えば $z_{n} S$ ）を入 れ，貣空度及二つの Source の加熱速度及溫度を適当に調節しつつ蒸着を行えば所望のものが得られる のである.之の実驗は当研究室の竹村, 沢木両君により目下淮行中のもので何れ詳しい事は他の機会に 発表したいが，予備的のものとして $\mathrm{M}_{g} \mathrm{~F}_{2}, Z_{n} \mathrm{~S}$ により製作した膜の分光反射曲線を測定して見を結果 は，真空度から， $n_{1}=1.4, n_{2}=2.1^{*}$ と考えて計算した值とよく一致した。

\section{7 結語}

以上不均一薄膜による反射防止の効果を考えたのであるがその結果ガラスとの境界に於ける膜の風折 率がガラスより高い場合には $n_{1}, n_{2}, \delta$ の組合はせにより随意に或波長に対して反射率を零から大きな 值に迄変える事が出來るととがわかつた．然しその分光反射率を見るとかなり残巣反射があり，此の点 は反射防止膜としては大きな欠点である．逆化此殘畄反射の多い特徵を用い，干涉フィルター等への 應用も考えられ，文高い反射率も自由に得られるからして吸收のない牛透膜としての應用も充分期待さ れ得るのである。終に本磻の計算を手傳つて戴いた斎藤文子氏に厚く御礼を申上げる.

\section{女 䰚}

1) 久保田広, 礁用物理 16. (1947) 184；17 (1948) 79.

2) G. Bauer, Ann. d. Phys. 5. (1934) 19

3) Gans, Ann. d. Phys. 45. (1915) 709

4) W. Kofink \& E. Menzer, Ann. d. Phys. 39. (1941) 388

5 ) H. Schröder, Ann. d. Phys. 39 (1941) 55

6) L. B. Lockhart \& P. King, J. O. S. A. 37 (1947) 689

7) P. King \& L. B. Lockhart, J. O. S. A. 36. (1946) 513

8 ) H. A. Tanner \& L. B. Lockhart, J. O. S. A. 36. (1946) 701

(24-7-5 受付)

* Optical Thickness は色に上り測定される。 